\title{
PENGARUH CORPORATE ACTION TERHADAP PENGAMBILAN KEPUTUSAN DALAM PEMBELIAN SAHAM (STUDI PADA INVESTOR DI KOTA MAKASSAR)
}

\author{
Ismail Badollahi \\ ismailbadollahi@unismuh.ac.id \\ A.Ifayani Haanurat \\ aifayanihaanurat@unismuh.ac.id \\ Kadriati hasyim \\ kadriatihasyim08@gmail.com \\ Fakultas Ekonomi dan Bisnis \\ Universitas Muhammadiyah Makassar
}

\begin{abstract}
This research uses quantitative methods. This study aims to examine and see the effect of Corporate Action consisting of dividends, right issues and stock split on decision making in purchasing shares. This study uses multiple regression analysis using a sample of 80 respondents, namely investors in the city of Makassar. The analytical tool used is the SPSS version 20 program. The results of this study are dividend variables that positively and significantly influence investors 'decision making in buying shares, right issue variables that are positive but not significant, although positive right issues do not affect investors' decision making in buying shares because they are not significant to decision making, Stock split variables are positive but not significant, although positive stock split does not affect investor decision making in buying shares because it is not significant to decision making
\end{abstract}

Key words : Dividend, Right Issue, Stock Split and Decision Making

\begin{abstract}
Abstrak
Penelitian ini menggunakan metode kuantitatif. Penelitian ini bertujuan untuk menguji dan melihat pengaruh Corporate Action yang terdiri dari dividen, right issue dan stock split terhadap pengambilan keputusan dalam pembelian saham. Penelitian ini menggunakan analisis regresi berganda dengan menggunakan sampel sebanyak 80 responden yaitu investor yang berada di Kota Makassar. Alat analisis yang digunakan adalah program SPSS versi 20. Hasil dari penelitian ini adalah variabel dividen yang secara positif dan signifikan mempengaruhi pengambilan keputusan investor dalam pembelian saham, variabel right issue yang secara positif tetapi tidak signifikan, meskipun positif right issue tidak berpengaruh terhadap pengambilan keputusan investor dalam pembelian saham karena tidak signifikan terhadap pengambilan keputusan, variabel stock split yang secara positif tetapi tidak signifikan, meskipun positif stock split tidak berpengaruh terhadap pengambilan keputusan investor dalam pembelian saham karena tidak signifikan terhadap pengambilan
\end{abstract}

Kata Kunci: Corporate Action,Dividen,Right Issue, Stock Split dan Pengambilan Keputusan 


\section{PENDAHULUAN}

Memasuki era globalisasi, persaingan usaha sangatlah ketat terutama di Indonesia kini lebih banyak investor asing yang menguasai pasar dibandingkan dengan investor domestik terutama di bidang pasar modal. Meskipun di Indonesia perkembangan Pasar Modal belakangan ini berkembang cukup stabil dan mengalami perkembangan yang sangat pesat dan memegang peranan penting dalam memobilisasi dana masyarakat, maka dari itu pemerintah harus tetap mendorong warga Indonesia untuk lebih maju dan lebih berusaha untuk tetap menstabilkan pasar agar berdampak positif bagi pemerintah maupun investor itu sendiri

Corporate Action yaitu setiap tindakan emiten yang memberikan hak yang sama kepada seluruh pemegang saham seperti Dividen, Right Issue dan Stock Split. Dividen adalah pembagian laba perusahaan kepada pemegang saham berdasakan persentase kepemilikan pemilik modal.(Hermuningsih dan Dewi : 2009). Right Issue yaitu hak memesan efek terlebih dahulu yaitu hak memesan efek terlebih dahulu bagi pemegang saham lama dari adanya penerbitan dari adanya penerbitan efek baru atau penambahan modal. Stock Split yaitu pemecahan jumlah lembar saham perusahaan menjadi lembar yang lebih banyak dengan menggunakan nilai nominal yan lebih rendah per lembar sahamnya secara proporsional.

Berhubungan dengan kondisi investor di kota Makassar ini cukup berkembang dibandingkan dengan tahun sebelumnya yaitu tahun 2018 sebanyak 10.552 investor di kota Makassar yang masih belum banyak masyarakat yang mengenal apa itu produk investasi di pasar modal. Dengan adanya edukasi yang terus dilakukan oleh Bursa Efek Indonesia kepada masyarakat perlahan banya masyarakat yang tertarik dan bertanya-tanya apa instrumen keuangan dalam pasar modal. Berdasarkan latar belakang yang telah diuraikan di atas maka penulis mengambil penelitian dengan judul "Pengaruh Corporate Action Terhadap Pengambilan Keputusan Dalam Pembelian Saham (Studi Pada Investor Kota Makassar)

\section{TINJAUAN PUSTAKA}

\section{a. Dividen}

Dividen merupakan keuntungan perusahaan yang dibagikan kepada pemegang perusahaan. Besarnya pembagian dividen yang diterima oleh pemegang perusahaan ditentukan dalam agenda rapat umum pemegang saham (RUPS). Dividen dibagikan sesuai dengan laba yang didapatkan perusahaan dan persentase yang dibagikan sesuai dengan hasil dari RUPS yang dapat di bayar sebagai dividen tunai dan dividen dalam bentuk saham. Pebagian dividen harus diumumkan sebelumm dividen tersebut menjadi kewajiban perusahaan. Pembagian dividen menjadi pertimbangan investor dalam pengambilan keputusan dalam pembelian saham.

Sulindawati dkk (2017) macammacam kebijakan yang terkait dengan dividen antara lain :

a. Kebijakan dividen yang stabil.

b. Kebijakan dividen dengan penetapan jumlah dividen minimal plus jumlah ekstra.

c. Kebijakan dividen dengan penetapan dividen payout ratioyang konstan. 
Ada perusahaan yang mempunyai kebijakan hanya membiayai ekspensinya dengan dana yang berasal dari sumber intern saja. Kebijakan tersebut dijalankan atas dasar pertimbangan bahwa kalau ekspansi dibiayai dengan dana yang berasal dari hasil penjualan saham baru akan melemahkan kontrol dari kelompok dominan didalam perusahaan. Kalau membiayai ekspansi dengan utang akan memperbesar risiko finansialnya. Mempercayakan pada pembelanjaan intern dalam rangka usaha mempertahankan kontrol terhadap perusahaan yang akan mengurangi dividen payout ratio-nya

\section{b. Right Issue}

Right Issue pada hakikatnya merupakan hak memesan saham terlebih dahulu yang diberikan kepada pemodal saat ini untuk membeli saham baru yang dieluarkan emiten dalam rangka penghimpunan dana (Tandelilin, 2010:37). Right issue ata dikenal dengan istilah HMETD atau Hak Memesan Efek Terlebih Dahulu. Right Issue adalah salah satu jenis corporate action yaitu upaya yang dilakukan oleh pihak perusahaan untuk penambahan modal untuk perusahaan itu sendiri. Right issue tujuannya untuk meningkatkan persentase kepemilikan pemegang saham atau bisa dikatan untuk meningkatkan jumlah saham yang beredar di perusahaan.

Bagi perusahaa-perusahaan paling tidak ada 2 alasan untuk melakukan right issue, yaitu :

1) Right issue dapat mengurangi biaya, karena right issue biasanya tidak menggunakan jasa penjamin (under writer)

2) Dengan adanya right issue berakibat jumlah saham perusahaan yang ada akan bertambah sehingga diharapkan akan meningkatkan frekuensi perdagangan atau yang berarti meningkatkan likuiditas saham.

\section{c. Stock Split}

Stock Split (pemecahan saham) adalah memecah selembar saham menjadi lembar saham. Harga per lembar saham baru setelah pemecahan saham adalah sebesar $1 / \mathrm{n}$ dari harga sebelumnya (Jogiyanto, 2000). Pemecahan saham (stock split) adalah perubahan nilai nominal per lembar saham dan menambah jumlah saham yang beredar sesuai dengan faktor pemecahan (split factor). Pemecahan biasanya dilakukan pada saat harga saham dinilai terlalu tinggi, sehingga akan mengurangi kemampuan investor untuk membelinya. Pada dasarnya pemecahan saham yan dapat dilakukan yaitu :

1) Pemecahan Naik (split factor) Pemecahan naik adalah penurunan nilai nominal per lembar saham yang mengakibatkan bertambahnya jumlah saham yang beredar, misalnya pemecahan saham dengan faktor $2: 1$, $3: 1,4: 1$

2) Pemecahan Turun (split down atau reverse split) Peningkatan nilai nominal per lembar saham dan mengurangi jumlah. saham yang beredar, misalnya $1: 2,1: 3,1: 4$

Alasan perusahaan melakukan pemecahan saham (stock split) adalah supaya harga sahamnya tidak terlalu tinggi, sehingga akan meningkatkan likuiditas perdagangannya. Sebalik-nya dengan alasan ini, yaitu likuiditas pasar akan semakin rendah setelah pemecahan saham (stock split), yaitu volume perdagangan menjadi lebih rendah dibandingkan sebelumnya, biaya 
transaksi pialang secara proporsi meningkatk dan bid -ask spread (selisih harga bid yang diajukan oleh pembeli dan harga ask yang diminta oleh penjual) juga lebih tinggi dari sebelumya (Jogiyanto,2000).

Ada dua teori penting mengenai fenomena pemecahan saham yaitu :

1) Signaling theory yang menjelaskan bahwa pemecahan saham (stock split) memberikan informasi kepada investor tentang prospek peningkatan return di masa depan yang substansial.

2) Trading range theory menyatakan bahwa pemecahan saham (stock split) dapat meningkatkan likuiditas perdagangan saham.

\section{d. Kerangka Pikir/ Kerangka Konsep}

Secara sederhana, kerangka pemikiran dalam penelitian ini ditunjukkan dengan bagan sebagai sebrikut:

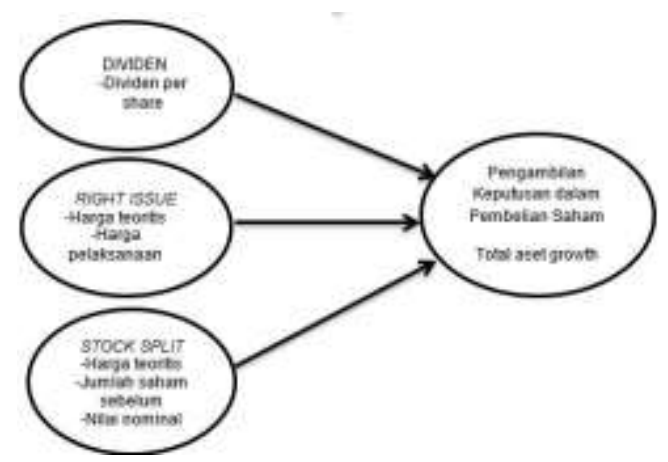

Sumber: Penulis, 2019

\section{METODE PENELITIAN}

\section{a. Teknik Analisis}

Teknik analisis data adalah suatu metode yang digunakan untuk mengolah hasil penelitian guna memperoleh suatu kesimpulan. Dengan melihat kerangka pemikiran teoritis, maka teknis analisis data yang digunakan dalam penelitian ini adalah uji normalitas dan uji hipotesis

1) Uji Keabsahan Data
Uji data diartikan sebagai upaya mengolah data menjadi informasi sehingga karakteristik atau sifat-sifat data tersebut dapat dengan mudah dipahami. Untuk menguji data dalam penelititan ini digunakan analisis sebagai berikut:

a) Uji Validitas

Menurut Sugiyono (2016:121) "instrumen yang valid berarti alat ukur yang digunakan untuk mendapatkan data (mengukur) itu valid'. Valid berarti instrument tersebut dapat digunakan untuk mengukur apa yang seharusnya diukur. Pengujian validitas tiap butir menggunakan analisis item, yaitu mengkorelasikan skor tiap butir dengan skor total yang merupakan jumlah dari keseluruhan skor tiap butir. Untuk menguji tingkat validitas data menggunakan program dengan menggunakan korelasi Bivariate Pearson. b) Uji Reliabilitas

Menurut Sugiyono (2016: 131), "Instrumen yang reliable adalah instrument yang bila digunakan beberapa kali untuk mengukur objek yang sama akan menghasilkan data yang sama. Pengujian reliabilitas instrumen dilakukan dengan program SPSS dengan menggunakan rumus Alpha Cronbach.

\section{b. Uji Hipotesis}

Untuk menguji hipotesis yang telah dikemukakan sebelumnya digunakan beberapa analisis sebagai berikut:

1) Regresi Linear Berganda

Analisis regresi berganda adalah analisis tentang hubungan antara dua atau lebih variabel bebas dengan satu variabel terikat dalam hal ini bertujuan memprediksi pengaruh dividen,stock split dan right issue terhadap pengambilan keputusan dalam pembelian saham. Analisis ini juga 
dilakukan untuk mengetahui arah hubungan antara variabel bebas dan variabel terikat berhubungan positif atau negatif. Menurut Sugiyono (2010: 267) analisis regresi ganda dilakukan dengan menggunakan rumus sebagai berikut:

$\breve{\Upsilon}=\alpha+\beta_{1} \cdot X_{1} \cdot \beta_{2} \cdot X_{2}$

Dimana:

$$
\begin{array}{ll}
\breve{\Upsilon} & =\text { Variabel Terikat } \\
\alpha & =\text { Konstanta } \\
\beta_{1} \beta_{2} & =\text { Koefisien regresi } \\
\mathrm{X}_{1} \mathrm{X}_{2} & =\text { Variabel bebas }
\end{array}
$$

\section{HASIL DAN PEMBAHASAN}

\section{a. Hasil Penelitian}

\begin{tabular}{|c|c|c|c|}
\hline \multicolumn{2}{|c|}{ Model } & \multicolumn{2}{|c|}{ Collinearity Statistics } \\
\hline & & Tolerance & VIF \\
\hline \multirow[t]{4}{*}{1} & (Constant) & & \\
\hline & Dividen & "913 & 1,095 \\
\hline & Right Issue & "773 & 1,294 \\
\hline & Stock Split & ,736 & 1,359 \\
\hline
\end{tabular}

1. Keabsahan Data

Hasil Uji Multikolonieritas Coefficents a

Sumber: Data sekunder yang diolah dengan SPSS 20,

$$
\text { Dari perhitungan Hasil Uji }
$$
Multikolonieritas pada tabel 4.8 di atas dapat dilihat bahwa tidak ada variabel independen yang memiliki nilai Tolerance kurang dari 0.10 yaitu 0.913 (Dividen), 0.773 (Right Issue), dan 0.736 (Stock Split). Hasil perhitungan Variance Inflation Factor (VIF) juga menunjukkan bahwa tidak ada satu variabel independen yang memiliki nilai VIF lebih dari 10, yaitu 1.095 (Dividen), 1.294 (Right Issue), dan 1.359 (Stock Split). Maka dapat disimpulkan bahwa persamaan model regresi yang diajukan bebas dari Multikolonieritas.

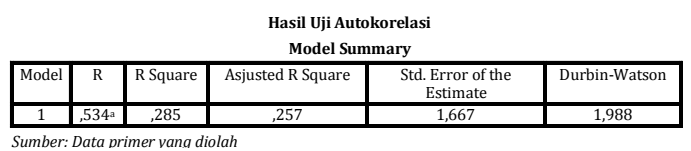

Pada tabel Uji Autokorelasi di atas terlihat angka D-W. Pada tabel di atas terlihat $\mathrm{R}$ Square sebesar 0,285 artinya model yang dibangun menggambarkan fakta pada pengambilan keputusan investor di Kota Makassar sebesar $28,5 \%$ dan sisa nya sebesar $71,5 \%$ yang merupakan keterbatasan

\begin{tabular}{|c|c|c|c|c|c|c|}
\hline \multicolumn{2}{|c|}{ Model } & \multirow{2}{*}{$\begin{array}{c}\begin{array}{c}\text { Sum of } \\
\text { Squares }\end{array} \\
84,121\end{array}$} & \multirow{2}{*}{$\begin{array}{l}\text { Df } \\
3\end{array}$} & \multirow{2}{*}{$\begin{array}{c}\text { Mean } \\
\text { Square } \\
28,040\end{array}$} & \multirow{2}{*}{$\begin{array}{c}F \\
10,096 \\
\end{array}$} & \multirow{2}{*}{\begin{tabular}{|c|} 
Sig. \\
, $000^{\mathrm{b}}$
\end{tabular}} \\
\hline 1 & \begin{tabular}{|l|} 
Regression \\
\end{tabular} & & & & & \\
\hline & Residual & $\overline{2211,079}$ & $\overline{776}$ & $2,2,777$ & & \\
\hline & Total & 295,200 & $\overline{79}$ & & & \\
\hline
\end{tabular}
instrumen penelitian yang digunakan serta erorr.

Hasil Uji Glejser Heteroskedastisitas

$$
\text { ANOVAa }
$$

Dilihat dari tabel 4.10 ini menunjukkan bahwa tidak ada satupun variabel independen ang signifikan secara statistik mempengaruhi variabel dependen nilai absolute residual, hal ni terlihat dari probabilitas signifikansinya di atas tingkat kepercayaan 5 persen. Jadi dapat disimpulkan bahwa model regresi yang digunakan tidak mengandung

\begin{tabular}{|c|c|c|c|c|c|c|}
\hline \begin{tabular}{|l|} 
Variabel \\
\end{tabular} & $\begin{array}{l}\text { Indikat } \\
\text { or }\end{array}$ & $\begin{array}{c}\text { Pearson } \\
\text { Correlatio } \\
\mathrm{n}\end{array}$ & $\begin{array}{l}\text { Sig. } \\
(2- \\
\text { Tailed } \\
)\end{array}$ & $\begin{array}{c}\text { Keteranga } \\
n\end{array}$ & $\begin{array}{l}\text { Cronbach } \\
\text { 's Alpha }\end{array}$ & $\begin{array}{c}\text { Keteranga } \\
n\end{array}$ \\
\hline \multirow{5}{*}{ Dividen } & $\begin{array}{l}\mathrm{X} 1.1 \\
\end{array}$ & 0,669 & 0,000 & Valid & \multirow{5}{*}{0,652} & Reliabel \\
\hline & X1.2 & 0,750 & 0,000 & $\begin{array}{l}\text { Valid } \\
\end{array}$ & & Reliabel \\
\hline & $\begin{array}{l}\mathrm{X} 1.3 \\
\end{array}$ & 0,682 & 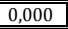 & Valid & & $\begin{array}{l}\text { Reliabel } \\
\end{array}$ \\
\hline & $\begin{array}{l}\mathrm{X} 1.4 \\
\end{array}$ & 0,696 & $\overline{0,000}$ & \begin{tabular}{c|} 
Valid \\
\end{tabular} & & $\begin{array}{l}\text { Reliabel } \\
\end{array}$ \\
\hline & X1.5 & 0,429 & 0,000 & VValid & & Reliabel \\
\hline \multirow{5}{*}{$\begin{array}{l}\text { Right } \\
\text { Issue }\end{array}$} & $\mathrm{X} 2.1$ & 0,782 & 0,000 & Valid & \multirow{5}{*}{0,815} & Reliabel \\
\hline & $\mathrm{X} 2.2$ & 0,762 & 0,000 & Valid & & Reliabel \\
\hline & $\mathrm{X} 2.3$ & 0,655 & 0,000 & Valid & & Reliabel \\
\hline & $\begin{array}{l}\mathrm{X} 2.4 \\
\end{array}$ & 0,782 & 0,000 & Valid & & Reliabel \\
\hline & X2.5 & 0,815 & 0,000 & $\begin{array}{l}\text { Valid } \\
\end{array}$ & & $\begin{array}{l}\text { Reliabel } \\
\end{array}$ \\
\hline \multirow{5}{*}{$\begin{array}{c}\text { Stock } \\
\text { Split }\end{array}$} & $\begin{array}{l}\mathrm{X} 3.1 \\
\end{array}$ & 0,680 & 0,000 & Valid & \multirow{5}{*}{0,606} & $\begin{array}{l}\text { Reliabel } \\
\end{array}$ \\
\hline & $\begin{array}{l}\mathrm{X} 3.2 \\
\end{array}$ & 0,716 & 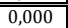 & $\begin{array}{l}\text { Valid } \\
\end{array}$ & & Reliabel \\
\hline & $\begin{array}{l}\mathrm{X} 3.3 \\
\end{array}$ & 0,434 & "0,000 & VValid & & Reliabel \\
\hline & X3.4 & 0,599 & 0,000 & Valid & & Reliabel \\
\hline & X3.5 & 0,661 & 0,000 & $\begin{array}{l}\text { Valid } \\
\end{array}$ & & Reliabel \\
\hline \multirow{5}{*}{$\begin{array}{c}\text { Pengamb } \\
\text { ilan } \\
\text { Keputusa } \\
\text { n }\end{array}$} & $\begin{array}{l}\text { Y.1 } \\
\end{array}$ & 0,571 & 0,000 & \begin{tabular}{c|} 
Valid \\
\end{tabular} & \multirow{5}{*}{0,637} & $\begin{array}{l}\text { Reliabel } \\
\end{array}$ \\
\hline & $\begin{array}{ll}Y .2 \\
\end{array}$ & 0,683 & 0 & Valid & & "Reliabel \\
\hline & Y.3 & 0,689 & 0,000 & Valid & & Reliabel \\
\hline & Y.4 & 0,624 & 0,000 & Valid & & Reliabel \\
\hline & Y.5 & 0,631 & 0,000 & Valid & & Reliabel \\
\hline
\end{tabular}
Heteroskedastisitas.

\section{Uji validitas}

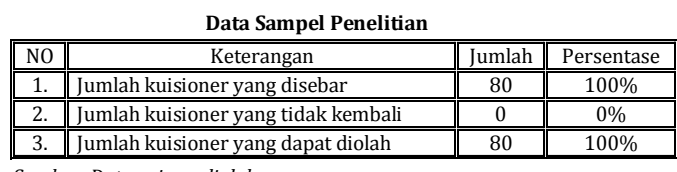

Sumber: Data primer diolah

Uji Validitas dan Realibilitas

Dari tabel 4.7 bahwa dalam uji validitas semua variabel bebas yaitu dividen, right issue, stock split menunjukkan kriteria yang valid untuk semua item pertanyaan dengan nilai signifikan lebih kecil dari 0,05. 
Sedangkan pengambilan keputusan menunjukkan bahwa kriteria valid degan nilai signifikan lebih kecil dari 0,05. Sedangkan dari tabel di atas menunjukkan cronbach' alpha atas variabel dividen sebesar 0,652, right issue sebesar 0,815, stock split sebesar 0,606 dan pengmbilan keputusan sebesar 0,637 dengan demikian, dapat disimpulkan bahwa pernyataan dalam kuisioner ini reliabel karena mempunyai nilai cronbach' alpha lebih besar dari 0,6 yang menunjukkan bahwa setiap item pertanyaan yang digunakan akan mampu memperoleh data yang konsisten yang berarti bila pernyataan itu diajukan kembali akan diperoleh jawaban yang relatif sama dengan jawaban sebelumnya.

3. Pengujian Hipotesis

\begin{tabular}{|c|c|c|c|c|c|c|}
\hline \multicolumn{7}{|c|}{ Hasil Analisis Regresi } \\
\hline $\begin{array}{l}\text { Variabel } \\
\text { Bebas }\end{array}$ & Variabel Terikat & B & Beta & $t$ & Sig. & Keterangan \\
\hline Dividen & $\begin{array}{l}\text { Pengambilan } \\
\text { Keputusan }\end{array}$ & 0,501 & 0,513 & 5,054 & 0,000 & Diterima \\
\hline Right Issue & $\begin{array}{l}\text { Pengambilan } \\
\text { Keputusan }\end{array}$ & 0,038 & 0,055 & 0,495 & 0,622 & Ditolak \\
\hline Stock Split & $\begin{array}{l}\text { Pengambilan } \\
\text { Keputusan }\end{array}$ & 0,018 & 0,022 & 0,194 & 0,847 & Ditolak \\
\hline$\overline{\bar{R}}$ & \multicolumn{6}{|l|}{$0,534 \mathrm{a}$} \\
\hline RSquare & \multicolumn{6}{|l|}{0,285} \\
\hline FF & \multicolumn{6}{|l|}{ 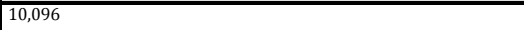 } \\
\hline
\end{tabular}

Pembuatan persamaan regresi berganda dapat dilakukan dengan menginterpretasikan angka-angka yang ada di dalam unstandardized coefficient beta. Berdasarkan perhitungan yang dilakukan menggunakan SPSS di atas maka di dapat persamaan regresi liner berganda model regresi sebagai berikut:

$$
\mathrm{Y}=10.396+0,501 \mathrm{X}_{1}+0,038 \mathrm{X}_{2}+
$$

Berdasarkan persamaan regresi tersebut dapat dianalisis pengaruh masing- masing variabel independen terhadap variavel dependen, yaitu sebagai nilai koefisien regresi 0,501 $\left(\mathrm{X}_{1}\right)$ pada variabel dependen terdapat hubungan positif dengan pengambilan keputusan. Hal ini menunjukkan kenaikan satu persen variabel dividen, dengan asumsi variabel lain tetap maka meningkatkan pengambilan keputusan.

Nilai koefisien regresi $0,038\left(\mathrm{X}_{2}\right)$ pada variabel dependen terdapat hubungan positif dengan pengambilan keputusan. Hal ini menunjukkan kenaikan satu persen variabel right issue, dengan asumsi variabel lain tetap maka meningkatkan pengambilan keputusan.

Nilai koefisien regresi 0,018 $\left(\mathrm{X}_{3}\right)$ pada variabel dependen terdapat hubungan positif dengan pengambilan keputusan. Hal ini menunjukkan kenaikan satu persen variabel stock split, dengan asumsi variabel lain tetap maka meningkatkan pengambilan keputusan

\section{b. Pembahasan Penelitian}

\section{Pengaruh dividen terhadap pengambilan keputusan dalam pembelian saham}

Dividen adalah keuntungan perusahaan yang dibagikan kepada pemegang saham perusahaan. Dividen dibagikan sesuai dengan persentase kepemilikan investor jadi semakin tinggi persentase kepemilikan pada suatu perusahaan maka semakin tinggi pula dividen yang akan diterima oleh investor.

Hipotesis pertama menyatakan bahwa dividen berpengaruh positif terhadap pegambilan keputusan dalam pembelian saham. Hasil statistik dapat dilihat pada pada nilai signifikansi pengujian sebesar 0,000 yang berada di bawah tingkat signifikansi yaitu 0.05 , sehingga variabel dividen ini dapat dijadikan indikator dalam pengambilan keputusan dalam pembelian saham.

\section{Pengaruh right issue terhadap pengambilan keputusan dalam pembelian saham}


Variabel Right issue dalam hal ini menunjukkan bahwa positif tetapi tidak signifikan sesuai yang terlihat pada pengujian sebesar 0.622 yang berada di atas tingkat signifikansi 0.05 , sehingga variabel right issue ini tidak dpat dijadikan indikator dalam pengambilan keputusan dalam pembelian saham karena tidak membuat investor mengambil keputusan dalam pembelian saham meskipun berpengaruh positif. Hal ini berarti bahwa right issue juga muncul atau diterima tidak mempengaruhi pengambilan keputusan dalam pembelian saham.

\section{Pengaruh stock split terhadap pengambilan keputusan dalam pembelian saham}

Variabel stock split dalam hal ini menunjukkan bahwa berpengaruh positif tetapi tidak signifikan sesuai yang terlihat pada pengujian sebesar 0.847 yang berada di atas tingkat signifikansi 0.05 , sehingga variabel stock split ini tidak dpat dijadikan indikator dalam pengambilan keputusan dalam pembelian saham karena tidak membuat investor mengambil keputusan dalam pembelian saham meskipun berpengaruh positif. Hal ini berarti bahwa stock split juga muncul atau diterima tidakmempengaruhi pengambilan keputusan dalam pembelian saham.

\section{PENUTUP}

\section{a. Simpulan}

Berdasarkan hasil analisis dan pemahasan yang telah dijelaskan pada bab sebelumnya, maka kesimpulan dari penelitian ini adalah :

1. Dividen berpengaruh posiif dan signifikan terhadap pengambilan keputusan dalam pembelian saham di
Kota Makassar. Maka variabel dividen dinyatakan berpengaruh.

2. Right issue positif tetapi tidak signifikan terhadap pengambilan keputusan dalam pembelian saham di Kota Makassar. Maka variabel right issue tidak berpengaruh terhadap pengambilan keputusan dikarekan ttidak signifikan.

3. Stock split positif tetapi tidak signifikan terhadapa pengambilan keputusan dalam pembelian saham di Kota Makassar. Maka variabel stock split tidak berpengaruh terhadap pengambilan keputusan dikarekan ttidak signifikan

\section{b. Saran}

Berdasarkan kesimpulan di atas maka adapun saran yang dapar siberkan kepada peneliti selanjutnya antara lain yaitu :

1. Penelitian selanjutnya diharapkan dapat menambah variabel-variabel penelitian yang lain.

2. Penelitian selanjutnya diharapkan dapat menggunakan alat analisa yang berbeda dengan penelitian sebelumnya.

3. Penelitian selanjutnya menggunakan indikator yang lebih bagus.

\section{DAFTAR PUSTAKA}

Agus, Sartono. 2008. Manajemen Keuangan Teori dan Aplikasi Edisis Empat.Yogyakarta: BPFE

Ajzen, I. 1991. Theory of Planned Behavior. Organizational Human Behavior and Human Decission Processes. 50, 179-211.

Andriza, R., \& Yusra, I. (2019). Pengaruh Kepemilikan Manajerial Dan Kebijakan Deviden Terhadap Kemakmuran Investor Dan Nilai 
Perusahaan Yang Tercatat Pada Indeks Lq45. Skripsi

Bringham, Eugene F., and Joel F. Houston. (2010). Dasar-Dasar Manajemen Keuangan : Assetials of Financial Management,Jakarta. Penerbit Salemba Empat.

Dermawan, Rizqi. 2004. Pengambilan Keputusan, Bandung :Alfabeta.

Dewi, N. P. S., \& Putra, I. N. W. A. (2013). Pengaruh pengumuman right issue pada abnormal return dan volume perdagangan saham. E-Jurnal Akuntansi Universitas Udayana, 3(3), 163-178..

Fahmi, Irham. 2013. Analisis Laporan Keuangan. Bandung: Alfabeta

Hadiwijaya, C. (2018). Analisis Perbandingan Abnormal Return Dan Likuiditas Saham Sebelum Dan Sesudah Stock Split Pada Perusahaan Yang Terdaftar

Di Bursa Efek Indonesia Periode 2010-2015. Jurnal Manajemen Bisnis dan Kewirausahaan, 3(1).

Hasan, M Iqbal 2002. Pokok-Pokok Materi Statistika I (Statistika Deskriptif).Edisi Kedua Pt. Bumi Aksara. Jakarta

Hermuningsih, S., \& Wardani, D. K. (2008). Analisis Reaksi Pasar Modal Terhadap Peristiwa

Right Issue Dan Pengumuman Dividend Yang Ditunjukkan Oleh Abnormal Return. Penelitian tidak dipublikasikan.

Hogan, Nicky. 2017. Yuk Nabung Saham. Jakarta: PT Elex Media Komputindo.

Ikatan Akuntansi Indonesia. 2017. Penyusunan dan Penyajian Laporan Keuangan sesuai PSAK 1, PSAK 2, PSAK 3, PSAK 25 dan ISAK 17. Jakarta Rajawali Persada.

Indarti, I., \& Purba, D. M. B. (2012). Analisis perbandingan harga saham dan volume perdagangan saham sebelum dan sesudah stock split. Jurnal Ilmu Ekonomi ASET, 13(1).

Jogiyanto, 2000, Teori Portofolio dan Analisis Investasi, Edisi 4, BPFE, Yogyakarta.

Jogiyanto, E. (2012). Teori Portofolio dan Analisis Sekuritas. Yogyakarta: BPFE Fakultas Ekonomi UGM.

Kusno, J. I., \& Hartanto, F. T. (2018). Dampak Pengumuman Pembagian Dividen Kas Terhadap Abnormal Return Pada Indeks LQ45. Jurnal Riset Akuntansi dan Keuangan, 6(3), 441-452.

Mulyadi (2001), Akuntansi Manajemen, Edisi 3, Penerbit Salemba Empat.

Nugraha, N. I., \& Wijayati, F. L. (2018). Peristiwa Stock Split: Analisis Aktivitas Perdagangan Saham Dan Return Saham Pada Perusahaan Di Bursa Efek Indonesia Tahun 2015-2017 (Doctoral dissertation, IAIN ska).

Pratama, I., Surya, G., \& Sudhiarta, G. M. (2014). Analisis Perbandingan Abnormal Return Saham Sebelum dan Sesudah Pengumuman Right Issue. EJurnal Akuntansi Universitas Udayana, 3(3), 161-174

Puspitaningtyas, Z. (2013). Perilaku Investor dalam Pengambilan Keputusan Investasi di Pasar Modal.

Puspitaningtyas, Z. (2013). Perilaku Investor dalam Pengambilan Keputusan Investasi di Pasar Modal.

Retnaningrum, M., \& Haryanto, T. (2018). Analisis Pengaruh Kebijakan Dividen Dan Leverage Terhadap Return Saham Dengan Pemoderasi Csr. Jurnal Ekonomi dan Bisnis Kontemporer, 2(02).

Rusliati, E., \& Farida, E. N. (2010). Pemecahan saham terhadap 
likuiditas dan return saham. Jurnal Bisnis dan Akuntansi, 12(3), 161-174.

Sakdiyah, H., Mahsuni, A. W., \& Mawardi, M. C. (2018). Pengaruh Minat Dan Perilaku Investor Terhadap Pilihan Keputusan Pada Investasi Beresiko. (Studi Kasus Pada Mahasiswa Jurusan Akuntansi Fakultas Ekonomi Dan Bisnis Universitas Islam Malang). Jurnal Riset Akuntansi, 7(01).

Sawidji Widoatmodjo, 2005, Cara Sehat Investasi di Pasar Modal, PT Elex Media Komputindo, Jakarta.

Sugiyono. (2013). Metode Penelitian Kuantitatif, Kualitatif Dan R\&D, Edisi ke - 19. Bandung : Alfabeta.

Sugiyono. 2015. Metode Penelitian Kuantitatif, Kualitatif, dan R\&D. Bandung: Alfabeta

Sulindawati, N.L.G.E., Yuniarta, G.A., Purnamawati, I.G.A.(2017). Manajemen Keuangan: Sebagai dasar pengambilan keputusan bisnis. Jilid I. Rajawali Pers: Depok.

Tandelilin, Eduardus. 2010. Analisis Investasi dan Manajemen Portofolio. Edisi Ketujuh.

Karnisius. Yogyakarta.

Trijunanto, E. (2016). Analisis Pengaruh Pemecahan Saham (Stock Split) Terhadap Abnormal Return Saham Dan Likuiditas Saham Pada Perusahaan Yang Terdaftar Di Bursa Efek Indonesia (Bei) Periode 2011-2015. Perbanas Review, $2(1$ 